\title{
TNRC6B wt Allele
}

National Cancer Institute

\section{Source}

National Cancer Institute. TNRC6B wt Allele. NCI Thesaurus. Code C134309.

Human TNRC6B wild-type allele is located in the vicinity of 22q13.1 and is approximately $291 \mathrm{~kb}$ in length. This allele, which encodes trinucleotide repeat-containing gene 6B protein is involved in translational repression. 